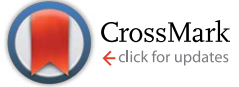

Cite this: RSC Adv., 2016, 6, 77256
Received 8th June 2016

Accepted 25th July 2016

DOI: $10.1039 / c 6 r a 14935 a$

www.rsc.org/advances

\section{Polyaminoacid-doxorubicin prodrug micelles as highly selective therapeutics for targeted cancer therapy $\dagger$}

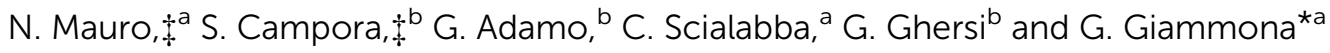

An amphiphilic copolymer carrying high-dose doxorubicin (21\% on a weight basis), PHEA-EDA-P,C-Doxo, was prepared by coupling doxorubicin with a biocompatible polyaminoacid through a $\mathrm{pH}$-sensitive spacer. Additional derivatization with 4-pentynoic acid endows it with self-assembling properties by means of $\pi-\pi$ stacking. These micelles can be triggered to promptly release drug in lysosomes ( $40 \%$ in $12 \mathrm{~h}$ ) through $\mathrm{pH}$ dependent micelle hydrolysis after uptake. In vitro tests on co-cultures of cancer (MDA-MB 231) and normal (HB-2) breast cells proved that the conjugate was selectively internalized into the former rather than normal cells, exploiting the caveolae-dependent endocytosis pathway, explaining the selective cytotoxic effect toward cancer cells. Intracellular trafficking study of MDA-MB 231 showed that the delivery of the endocytosed drug occurs through the direct fusion of caveosomes with late lysosomes, triggering a massive release in the cytoplasm, bringing about cell death. Dose-effectiveness and mechanistic data indicate that PHEA-EDA-P,C-Doxo is endowed with a distinctive combination of selectivity and pharmacological potency (EC50 $13 \mu \mathrm{M}, E_{\max }=77 \%$ and EC50 > $25 \mu \mathrm{M}, E_{\max }=21 \%$ for cancer and healthy cells respectively) that makes it an excellent candidate for future preclinical studies.
\end{abstract}

\section{Introduction}

Considerable attention is being focused at the present on smart nanomedicines for targeted drug delivery as they are promising implements to overcome limitations of conventional anticancer approaches, such as the lack of selectivity toward cancer cells as well as the poor bioavailability. ${ }^{\mathbf{1 , 2}}$ Smart nanomedicines may act as specific drug release systems by means of the enhanced

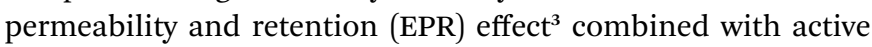
targeting toward membrane molecules overexpressed by cancer cells (e.g., growth factors, peptides such as RGD or proteins), thus allowing drug accumulation into the tumor and avoiding multidrug resistance phenomena., ${ }^{2,4-6}$

Recent attempts to develop effective nanomedicines with selective anticancer properties have not yet seen satisfying

\footnotetext{
${ }^{a}$ Laboratory of Biocompatible Polymers, Department of Scienze e Tecnologie Biologiche, Chimiche e Farmaceutiche (STEBICEF), University of Palermo, Via Archirafi, 3290123 Palermo, Italy. E-mail: gaetano.giammona@unipa.it; Fax: +39 09123891928; Tel: +39 09123891928

${ }^{b}$ Department of Scienze e Tecnologie Biologiche, Chimiche e Farmaceutiche (STEBICEF), University of Palermo, Viale delle scienze Ed., 1690128 Palermo, Italy $\dagger$ Electronic supplementary information (ESI) available: Viability assay on HCT 116, SK-HEP-1 and 16HBE for doxorubicin hydrochloride and PHEA-EDA-P,C-Doxo after 24 and $48 \mathrm{~h}$ of incubation; relative uptake expressed as Doxo/FITC fluorescence ratio on MDA-MB 231 and HB-2; fluorescence microscopy of co-culture of MDA-MB 231 and HB-2 cells incubated with $10 \mu \mathrm{M}$ PHEA-EDA-P,C-Doxo and doxorubicin alone. See DOI: 10.1039/c6ra14935a

\$ These authors contributed equally to this work.
}

results in clinical applications. For instance, doxorubicinloaded PEGylated liposomes (DOXIL $®$ ), the first FDA-approved nanomedicine for targeted therapy of Kaposi's sarcoma, thus far have not shown a good clinical performance albeit they mostly exhibit reduced incidence of side effects. ${ }^{7}$ Besides, EPRexploiting PEGylated nanoparticles, such as NK911 (PEG-polyaspartic micelles) and Genexol-PM (PEG-PLA micelles), have largely failed to really improve response rates and survival times of treated patients. ${ }^{8}$ This because PEGylation of such nanosystems allows reaching of a tumor by the EPR effect, but at the same time the hydrophilic shell obstructs an optimal and fast uptake by cancer cells within the tumor thus releasing the payload into the tumor milieu rather than within cancer cells (PEG dilemma)., ${ }^{\mathbf{9} 10}$ On the other hand, notwithstanding that polymeric supramolecular nano-sized aggregates provide an excellent platform to specifically deliver anticancer agents, their thermodynamic instability in physiological medium can drastically decrease the therapeutic efficacy. ${ }^{\mathbf{1 1}}$ Indeed, after their disassembly the drug payload diffuses throughout the bloodstream giving a typical therapeutic profile of the free drug, including low bioavailability and lack of specificity. Hence, more complex approaches in terms of drug release mechanisms and surface proprieties should be considered.

The synthesis of prodrugs capable of self-assembling into micelles in aqueous media has received great attention for circumventing these drawbacks, since they can load suitable amount of drug, protect it against degradation phenomena taking place after intravenous administration (e.g., in lysosomes 
or in plasma) and may cleverly enter cancer cells and release their payload at the site of action following specific stimuli. ${ }^{12,13}$ Furthermore, this being a self-assembled system constituted by macromolecular unimers which themselves contain the covalently bonded drug, it may act as an EPR-based drug delivery system independently by its stability after administration. For instance, the anticancer effect of chitosan-irinotecan prodrugs with self-assembling ability has been evaluated in vitro and in vivo demonstrating that a substantial reduction of a tumor mass can be obtained as a consequence of the improved pharmacokinetic profile. ${ }^{14}$ More recently we developed an EPR-based $\mathrm{pH}$ sensitive inulin-doxorubicin conjugate endowed with selfassembling and charge reversal abilities. ${ }^{15,16}$ We provided evidence of enhanced internalization of this system in cancer cells instead of the normal counterpart thanks to the conjugate's ability of releasing doxorubicin and reversing its net charge, from negative to positive, once the cancer site is reached, thus improving the preferential release of the drug at the site of action and throughout the inside of cells. This outcome was accomplished by exploiting a pH-sensitive cleavage mechanism triggered by the acidic $\mathrm{pH}$ of cancer cells $(6.4<\mathrm{pH}<5.5)$.

Here, we worked along the same lines as that $\mathrm{pH}$-sensitive conjugate to learn how to improve its anticancer specificity as a function of the main features of the polymeric backbone. High molecular weight $\alpha, \beta$-poly( $N$-2-hydroxyethyl)-D,L-aspartamide (PHEA) was chosen as main macromolecule, instead of inulin, since it is a biocompatible polyhydroxylated polymer as inulin is but with a molecular weight up to ten times higher. ${ }^{17-19}$ This implies improved EPR effect and enhanced loading capability, which usually favorably affect the effectiveness of such vehicles. ${ }^{20,21}$

In this work we studied the self-assembling ability of this conjugate and its $\mathrm{pH}$-sensitive drug release both in plasma and in artificial lysosomal fluid. The cytotoxicity of this conjugate was systematically investigated using cancer and normal cell lines, both as single cell line or as co-culture, so as to assess the selective effect toward cancer cells instead of the normal ones. In addition, mechanistic aspects of the cellular uptake and intracellular trafficking were investigated with breast cancer cells to understand the intracellular fate and mode of action of the conjugate. The aim of this paper is to report on this.

\section{Results and discussion}

In a previous work it has been demonstrated that citraconic anhydride can be used as a multi-purpose reactant in order to bring into the main chain of polyhydroxylated polymers free ionizable carboxylic groups, whose ionization degree affects the physicochemical properties of the copolymer, and simultaneously to allow for doxorubicin conjugation via labile amidic bonds that rapidly hydrolyze under slight acidic conditions $\mathrm{pH}$ $<6.5) .{ }^{15}$ It was reported that the free carboxylates make the system prevailingly anionic until the cancer tissue is reached $(\mathrm{pH}<6.5)$, avoiding the typical toxicity profile of common polycations and ensuring that the drug payload is preferentially released at the site of action. ${ }^{15,22}$ Besides, it was shown that $\pi-\pi$ interactions taking place between doxorubicin and pentin moieties lead to organized supramolecules in water.

Taking into account these insights, herein, a $\mathrm{pH}$-sensitive conjugate, henceforth named PHEA-EDA-P,C-Doxo, was synthesized as drug-polymer conjugate, carrying a high amount of doxorubicin, capable of self-assembling into smart supramolecules useful as EPR-based anticancer systems. The inulinbased backbone proposed in the first study was replaced here by PHEA, consisting of a polyaminoacidic backbone bearing one hydroxyl group per repeat unit. This polymer has a molecular weight about ten times higher than inulin, implying that each macromolecular chain can be functionalized with higher amount of doxorubicin as side group and still keeping a good dispensability in aqueous media. As a consequence, improved thermodynamic stability of the assembled supramolecules, in situ accumulation of the drug and higher anticancer selectivity toward cancer cells might be expected.

\section{Synthesis of the PHEA-doxorubicin conjugate}

The PHEA-EDA-P,C-Doxo conjugate was firstly synthesized by coupling pentynoic acid to PHEA-EDA using EDC/NHS as activating agents. The intermediate was derivatized with citraconic anhydride to obtain pH-sensitive citraconate side functions, which were partially functionalized with doxorubicin leading to a random copolymer bearing the drug and both remaining free carboxyl and amine functions (Scheme 1).

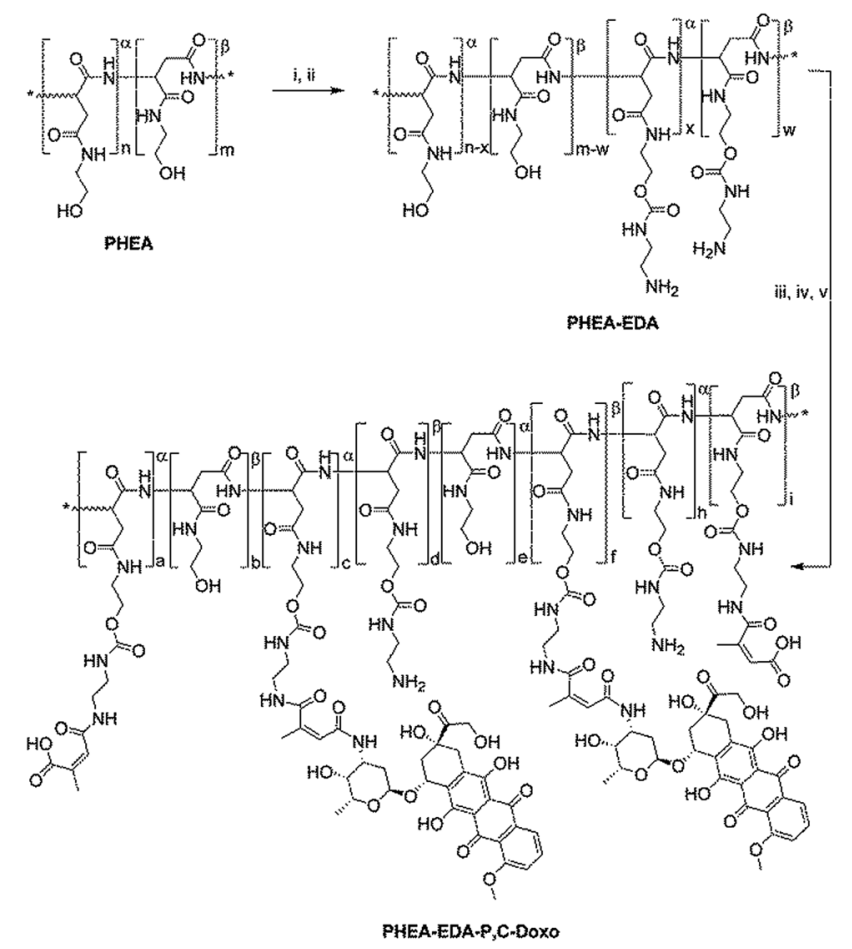

Scheme 1 Synthesis of PHEA-EDA-P,C-Doxo: (i) bis(4-nitrophenyl) carbonate, $\mathrm{DMF}, 40 \mathrm{~min}, 40^{\circ} \mathrm{C}$; (ii) EDA, 60 min, r.t.; (iii) EDC-HCl, NHS, pentynoic acid, phosphate buffer, $\mathrm{pH} 6.8,18$ h, r.t.; (iv) citraconic anhydride, water, $\mathrm{pH} 8-9,3 \mathrm{~h}$, r.t.; (v) EDC-HCl, NHS, doxorubicin hydrochloride, phosphate buffer $\mathrm{pH}$ 6.8/DMF $6: 4,18$ h, r.t. 
In a first step PHEA, a linear polyaminoacid consisting of $\mathrm{D}^{-}$or L-aspartamide repeat units regularly arranged into the polymer backbone, was partially functionalized with ethylenediamine (EDA) in order to introduce primary amine functions that are amenable to structure-tailoring for specific purposes (Scheme 1). ${ }^{21}$ A derivatization degree in EDA of $21.4 \mathrm{~mol} \%$ was obtained (DD $D_{\mathrm{EDA}}$, related to PHEA monomer units). $\mathrm{C}_{5}$-Alkyne side chains were introduced into the PHEA-EDA backbone in aqueous environment and without adding catalysts. This reaction involved EDA amine pendants and the carboxyl group of pentynoic acid (P) giving rise to the formation of stable amidic bonds. Citraconic anhydride (C) was then employed as heterobifunctional linker capable of easily reacting with the EDA amine residues without requiring additional purification steps. The scope of this functionalization was manifold. First of all, the derivatization of amine groups with acid-labile amide functions is reversible at the cancer microenvironment (acidic $\mathrm{pH}$ ) thus allowing charge reversal upon the hydrolysis (from negative to positive) to selectively improve cell internalization and therapeutic efficacy. On the other hand, the weakly acid carboxyl functional groups $\left(\mathrm{p} K_{\mathrm{a}}>4\right)$ are liable to subsequent reactions with other amine moieties. After purification from by-products through exhaustive dialysis, the hypothesized structure was confirmed and the mol\% of $\mathrm{P}$ and $\mathrm{C}$ functions, evident from ${ }^{1} \mathrm{H}$ NMR spectrometry, were calculated from the integrals of the peaks at $\delta 1.91$ and $\delta 1.93 \mathrm{ppm}$, related to $\mathrm{CCH}(\mathrm{P})$ and $\mathrm{HOOCCH}_{2} \mathrm{CH}_{3} / \mathrm{NHCOCH}_{2} \mathrm{CH}_{3}$ (C) hydrogens respectively, in comparison with that at $\delta 2.75 \mathrm{ppm}$ attributable to the $\mathrm{CH}_{2}$ of the polymer backbone (Table 1 ).

PHEA-EDA-P,C provided a large amount of carboxylic functions available for doxorubicin conjugation. The reaction involved the primary amine group of doxorubicin and these free carboxylates conveniently activated by a mixture of EDC and NHS and employing excess doxorubicin to maximize the polymer functionalization. The structural identification of PHEAEDA-P,C-Doxo was realized by ${ }^{1} \mathrm{H}$ NMR spectroscopy, whose assignments were in full agreement with the proposed compound.

The molar derivatization degree of doxorubicin $\left(\mathrm{DD}_{\mathrm{Doxo}}\right.$, $8.0 \%$ ), that is, the percentage of linked doxorubicin with respect to the repeat units, was calculated from the integrals of the peaks at $\delta 1.22$ and 2.75 ppm relative to the $\mathrm{CH}_{3} \mathrm{CH}_{2} \mathrm{O}$ (Doxo) and $-\mathrm{CH}_{2}$ (PHEA) hydrogens respectively.
It should be noticed that the amount of hydrophobic side functions, namely $\mathrm{P}$ and Doxo repeat units, was about 46 per macromolecule (13.1 mol\% of the repeat units), which was enough for achieving intramolecular or intermolecular selfassembly of the conjugate. Hence, the desolvation of the aromatic moieties can explain quite well the distortions observed at $\delta$ 7-8 ppm in the ${ }^{1} \mathrm{H}$ NMR spectrum (Zeeman and dipolar effects). It is noteworthy that the amount of doxorubicin in the copolymer evaluated spectrophotometrically (data not shown) confirmed that calculated by ${ }^{1} \mathrm{H}$ NMR, which correspond to $21.4 \% \mathrm{w} / \mathrm{w}$ (expressed as doxorubicin hydrochloride weight equivalent).

Weight average molecular weights $(\mathrm{Mw})$ and polydispersity of the synthesized conjugate and the intermediates where obtained by size exclusion chromatography (SEC) analyses using a calibration curve of monodisperse PEG standards with Mw ranging from 0.5 to $210 \mathrm{kDa}$ (Table 1). The relative molecular weight of the conjugate $(\mathrm{Mw}=57.8 \mathrm{kDa})$ showed a significant increase with respect to the parent copolymers (PHEA-EDA, Mw $=29.7 \mathrm{kDa}$; PHEA-EDA-P,C, Mw $=37.9 \mathrm{kDa}$ ) resulting from doxorubicin derivatization, keeping appropriate polydispersity.

\section{Physicochemical characterization of the conjugate}

It has been reported that amphiphilic polymers, which selfassemble into micelles by increasing their concentration in aqueous solution, showed a reduction of the viscosity curve (reduced viscosity VS concentration) slope near the critical aggregation concentration, ascribable to a volume contraction of the whole polymer chains. Consequently, the self-assembling ability of the conjugate was investigated viscosimetrically in water, at $25{ }^{\circ} \mathrm{C}$, and in a diluted regimen $\left(0.01\right.$ and $\left.0.125 \mathrm{~g} \mathrm{dL}^{-1}\right)$ (Fig. 1).

Not surprisingly, the plot of $\eta_{\text {red }} v s$. C was bimodal. In particular, it was linear below $0.036 \mathrm{~g} \mathrm{dL}^{-1}$ with the intercept ([ๆ]) equal to $0.128 \mathrm{dL} \mathrm{g}^{-1}$. Beyond this concentration the curve sharply decreased in slope, showing that, according to Einstein's equation, aggregation of the system occurred, giving rise to micelles carrying doxorubicin in their core.

The ability of the copolymer to lead to nano-sized micelles was also assessed by AFM microscopy. AFM micrograph (Fig. 2) shows that the conjugate assembled into homogeneous micelles with a spherical morphology and dimensions of about $15 \pm 2 \mathrm{~nm}$. INU-EDA-P,C-Doxo being designed to undergo

Table 1 Molar derivatization degree in EDA, P, C and Doxo linked to PHEA; and molecular weight (Mw), polydispersity and yield of the parent copolymers

\begin{tabular}{|c|c|c|c|c|c|c|c|}
\hline Sample & \multicolumn{7}{|c|}{ Composition } \\
\hline PHEA-EDA-P,C & 37.9 & 1.81 & 21.1 & 6.0 & 14.2 & - & 82 \\
\hline PHEA-EDA-P,C-Doxo & 57.8 & 1.61 & 21.4 & 5.1 & 13.9 & 8.0 & 76 \\
\hline
\end{tabular}

${ }^{a}$ Calculated by means of ${ }^{1} \mathrm{H}$ NMR spectroscopy. ${ }^{b}$ Calculated by combining ${ }^{1} \mathrm{H}$ NMR spectroscopy and UV spectrophotometry. ${ }^{c}$ Obtained by SEC analysis in $0.1 \mathrm{M} \mathrm{LiBr}$ DMF solution. 


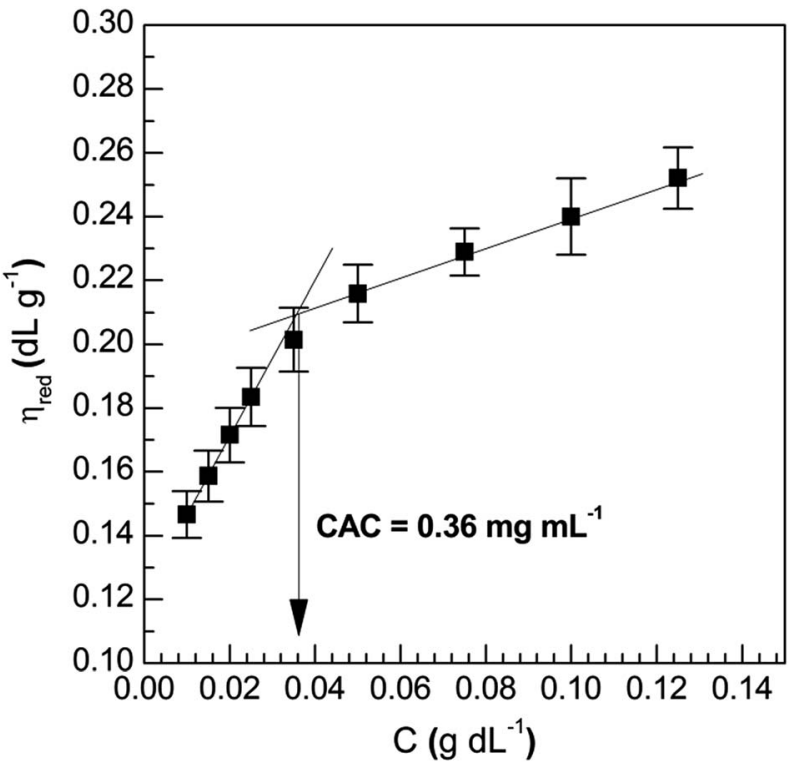

Fig. 1 Reduced viscosity of PHEA-EDA-P,C-Doxo $\left(\eta_{\text {red }}\right)$ as a function of concentration: the critical aggregation concentration (CAC) is represented by an arrow.
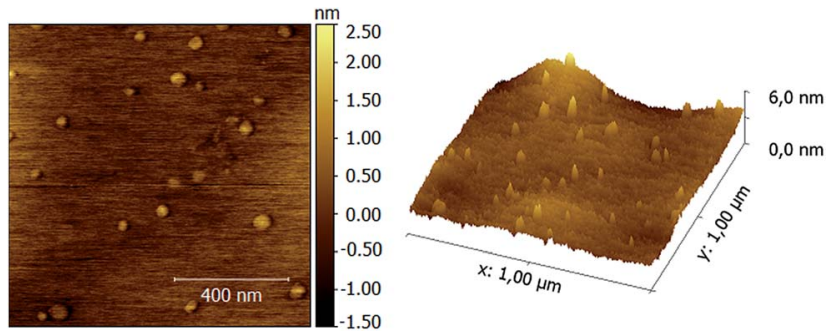

Fig. 2 AFM image of the conjugate-based micelles obtained from aqueous solution.

a pH-dependent charge inversion (from negative to positive) at the tumor site, where the $\mathrm{pH}$ is slightly acidic, its $\zeta$-potential was examined at different $\mathrm{pH}$ (Fig. 3). These experiments give us deeper insight into the conjugate uptake potentiality once the tumor is reached, since it is known that cationic nanosystems are internalized more quickly than anionic nanosystems. ${ }^{23,24}$

For comparative purposes, the same experiment was performed using PHEA-EDA as parent compound, whose $\zeta$ potential value was in the range $+19 \mathrm{mV}$ to $+31 \mathrm{mV}$ along the whole $\mathrm{pH}$ range considered $(2<\mathrm{pH}<7)$. PHEA-EDA-P,C-Doxo displayed a non-obvious trend: the $\zeta$-potential increased from $\approx-18$ to $-22 \mathrm{mV}$ on passing from $\mathrm{pH} 7$ to $\mathrm{pH}$ 6.1, than, coherently decreased until $\mathrm{pH} 3.8$ reversing its net charge and reaching a potential of $+12 \mathrm{mV}$. These results provide good evidence that, although at the beginning $(\mathrm{pH} 7 \geq 6)$ citraconateDoxo cleavage somewhat prevails over the INU-EDA-citraconate one, thereby increasing the amount of anionic charges, at $\mathrm{pH}$ below 6.2 the latter predominates giving primary amines and thus supplying charge inversion.

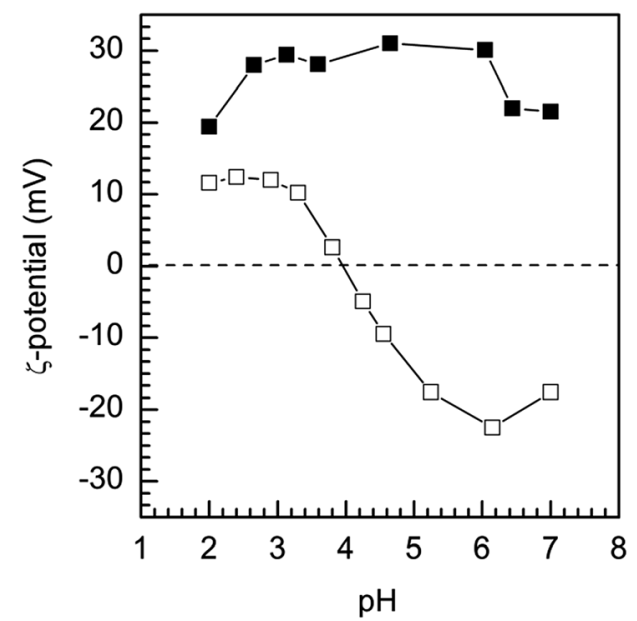

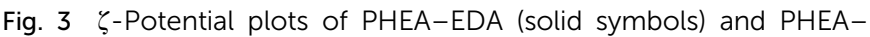
EDA-P,C-Doxo (open symbols) measured at $\mathrm{pH}$ range $7-2$.

\section{Drug release study}

Release experiments were carried out in human plasma and artificial lysosomal fluid (ALF), $\mathrm{pH}$ 5.0, simulating in turn the human body compartment after intravenous administration and after cell internalization. In addition, a typical distribution profile for polymeric nanosystems was mimicked consisting of a first circulation in the bloodstream for $6 \mathrm{~h}$ and subsequent cell uptake.

The dialysis equilibrium time, previously determined employing equivalent amount of doxorubicin hydrochloride at both $\mathrm{pH}$ values, was not dependent on the medium and was reached after $1.5 \mathrm{~h}$ (data not shown). Fig. 4 shows that PHEA-

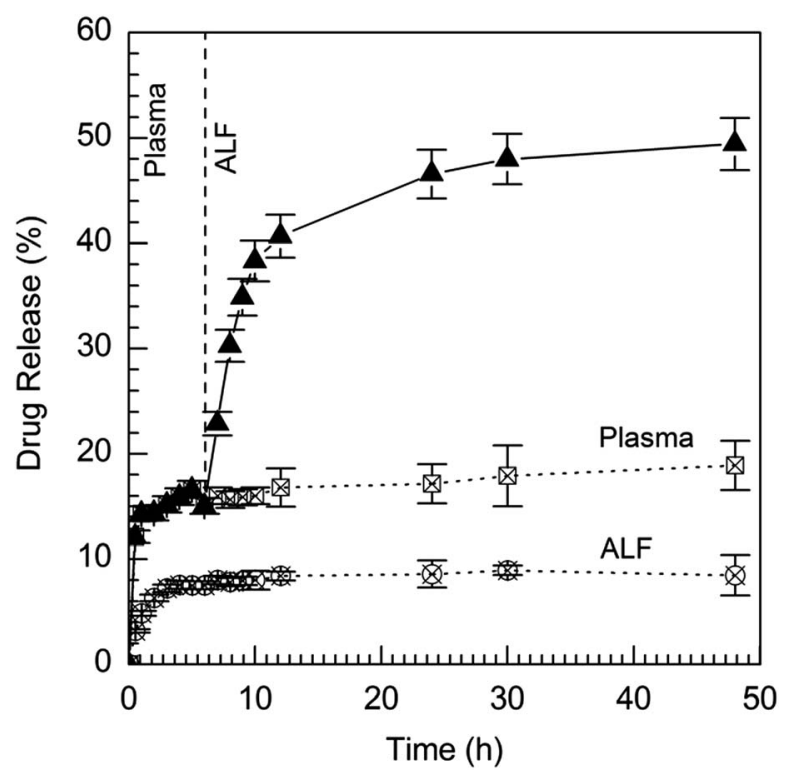

Fig. 4 Release profile for PHEA-EDA-P,C-Doxo at $37^{\circ} \mathrm{C}$ in artificial lysosomal fluid (ALF) at $\mathrm{pH} 5.0$ (open circles), human plasma (open squares) and changing the release medium from plasma ( $6 \mathrm{~h}$ ) to ALF (42 h) (solid symbols). 
EDA-P,C-Doxo proved capable of releasing doxorubicin in both media providing good evidence that citraconylamide groups, as suggested by the $\zeta$-potential experiments, were reversible. However, a remarkable $\mathrm{pH}$-dependent release profile can be noticed after $30 \mathrm{~min}$ of incubation without hinting at a "burst effect". Not surprisingly, the amount of doxorubicin released in plasma was about two times higher than that released in ALF (19\% vs. 9\%), suggesting that direct protonation of free carboxyl groups prevails over hydrolytic cleavage at slightly acidic $\mathrm{pH}$ (protonation is kinetically favorable over hydrolysis).

Indeed, additional structuration of micelles into collapsed hydrophobic domains occurred after their direct exposure at acidic $\mathrm{pH}$, thus avoiding hydrolysis of citraconylamide pendants and, as a consequence, doxorubicin release. Notably, this is in agreement with the $\zeta$-potential trend observed on varying the $\mathrm{pH}$ of the medium, in which a weak citraconylamide cleavage was recorded at pH 5-6 (Fig. 3). On the contrary, micelles previously incubated in plasma for $6 \mathrm{~h}$ released about $50 \%$ of their drug payload in ALF as a result of the preliminary hydrolysis of the superficial carboxyl groups at physiological $\mathrm{pH}$, which led to relaxed architectures (swollen micelles) with pronounced drug release profile inside lysosomes.

\section{Biological characterization}

Erythrocompatibility and cytotoxicity assay for PHEA-EDAP,C-Doxo micelles. Erythrolysis test was carried out at a concentration of micelles a thousand times higher than that predicted for future in vivo studies $\left(2.5 \mathrm{mg} \mathrm{mL}{ }^{-1}\right)$. The hemoglobin detected was about $0.6 \%$ with respect to the positive control pointing out that PHEA-EDA-P,C-Doxo prodrug micelles were not hemolytic.

Cytotoxicity assay for the PHEA-EDA-P,C-Doxo conjugate. In order to evaluate a specific cytotoxic effect of PHEA-EDA$\mathrm{P}, \mathrm{C}-\mathrm{Doxo}$ on cancer cells, viability assays were carried out for both normal (HB-2) and cancer (MDA-MB 231) cells of the same tissue (mammary tissue). Samples were incubated for $24 \mathrm{~h}$ with different concentrations of the conjugate or free doxorubicin (Doxo) as positive control $(0.5,2,3.5,5,10,15,20,25 \mu \mathrm{M})$ and the viability was estimated by CCK- 8 assay: the absorbance

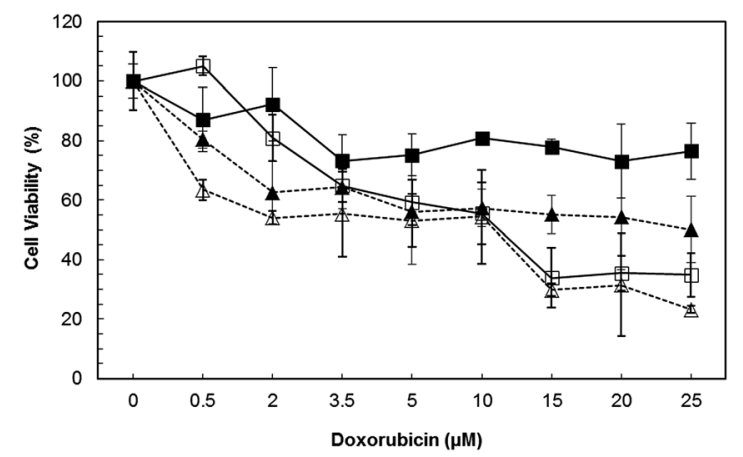

Fig. 5 Viability assay for MDA-MB 231 (open symbols) and HB-2 (solid symbols) treated with free doxorubicin (dashed lines) and PHEA-EDAP,C-Doxo (solid lines). values were expressed as a percentage considering untreated cells as having $100 \%$ viability (Fig. 5).

For PHEA-EDA-P,C-Doxo there were no considerable differences between the two cell lines treated with the conjugates at low doxorubicin concentrations $(0.5,2,3.5 \mu \mathrm{M})$. However, at $5 \mu \mathrm{M}$ it was possible to identify a modest dissimilarity of the cytotoxic effect of PHEA-EDA-P,C-Doxo (75\% HB-2 vs. 59\% MDA-MB 231 cell viability).

The gap increased at $10 \mu \mathrm{M}(80 \%$ vs. 55\%) and even more at $15 \mu \mathrm{M}$ with $78 \%$ viability for normal cells and $33 \%$ for cancer ones; these percentage values were maintained also at 20 and 25 $\mu \mathrm{M}$, suggesting a plateau state in which PHEA-EDA-P,C-Doxo cytotoxic effects registered were the maximum possible. It should be noticed that, apart from the enormous difference in terms of maximum efficacy $\left(E_{\max }\right)$ observed for the normal and cancer cell lines ( $21 \%$ vs. $77 \%$ respectively), the EC50 was significantly lower for the cancer cells $(\mathrm{EC} 50=13 \mu \mathrm{M})$. Also, this value was close to the EC50 calculated for free Doxo for both cell lines $(\sim 12 \mu \mathrm{M})$. Therefore, these data seem to suggest a powerfully selective anticancer activity of the conjugate toward cancer cells accompanied by a proper pharmacological potency, i.e., comparable to the free drug. Hence, the high selectivity observed in vitro will determine how well the conjugate can perform its anticancer activity in vivo, independently of the known EPR effect.

The cytotoxic activity of the conjugate was further investigated in other normal (16 HBE) and cancer (SK-HEP-1 and HCT 1161) cell lines (see ESI, Fig. S1†), confirming the selectivity described above.

Uptake studies by flow cytometry. Uptake studies were carried out to investigate if the difference in cytotoxic effect of PHEA-EDA-P,C-Doxo drug between cancer and healthy cells was due to a different internalization level. In this context, cells were incubated with a fluorescein isothiocyanate (FITC)labelled conjugate (PHEA-EDA-P,C-FITC-Doxo) in order to permit one to follow both the conjugate, thanks to FITC probe (green fluorescence), and doxorubicin (red auto-fluorescence). The quantitative uptake was investigated by flow cytometry following in the course of time (1, 2, 4, 6, 8 and $24 \mathrm{~h})$ the green

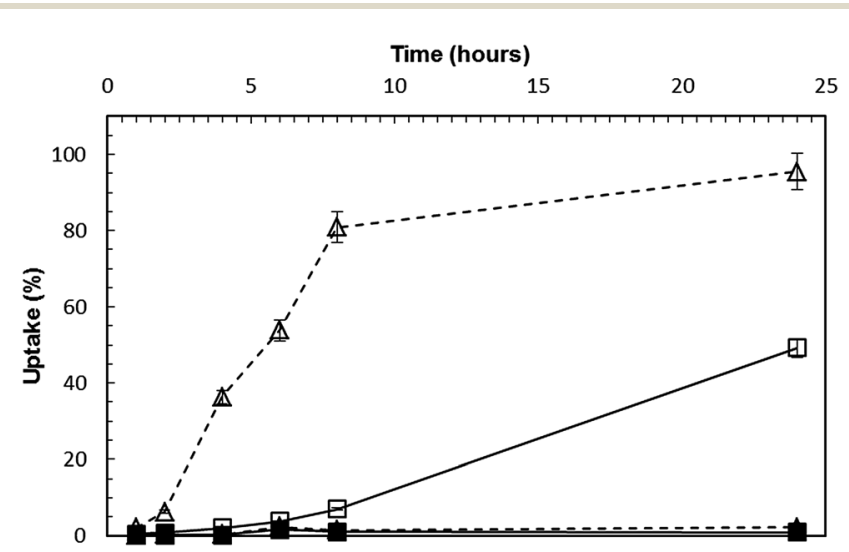

Fig. 6 Quantitative uptake of PHEA-EDA-P,C-FITC-Doxo by MDAMB 231 (open symbols) and HB-2 (solid symbols). Solid lines: FITC; dashed lines: doxorubicin. 
and the red fluorescence inside MDA-MB 231 and HB-2 cells, incubated with PHEA-EDA-P,C-FITC-Doxo (Fig. 6).

In cancer cells, the green fluorescence, relative to the polymer backbone, increased slightly for the first hours of treatment $(1,2,4,6$ and $8 \mathrm{~h})$ and much more after $24 \mathrm{~h}$. However, it was always higher than that in healthy cells indicating a higher uptake level for the conjugate in cancer cells rather than in the normal ones.

Fig. 6 shows also that the amount of doxorubicin in cancer cells augmented very quickly over time $(1,2,4,6 \mathrm{~h})$ reaching the maximum value after $8 \mathrm{~h}$ and maintaining it at this level also after $24 \mathrm{~h}$. It is important to note that the green and the red fluorescence in MDA-MB 231 did not grow in the same manner: the drug amount was higher in all times analysed in contrast with HB-2 in which the two fluorescence signals were at the same level until $4 \mathrm{~h}$. This behaviour leads us to hypothesize a model in which there was a partial drug release in the cell microenvironment. In particular, it is known that tumour microenvironments present a lower $\mathrm{pH}$ (about 6.5) than healthy ones (about 7.4). ${ }^{25}$ Since Doxo was bound through a $\mathrm{pH}^{-}$ sensitive linker to the copolymer, a partial drug release in cancer microenvironment can occur allowing the independent doxorubicin uptake with respect to the parent conjugate, while in the normal microenvironment the conjugate remained stable and went unchanged inside cells. Notably, in agreement with the above reported observations, free doxorubicin in the cell culture medium was about $3 \%$ after $24 \mathrm{~h}$ incubation, confirming that it was hydrolysed at the tumor microenvironment (data not shown). The relative uptake expressed as Doxo/FITC fluorescence ratio would explain better this model (see ESI, Fig. S2†).

These data were confirmed also by fluorescence microscopy analysis on normal and tumour cells (see ESI, Fig. S3†).

Localization studies in co-culture experiments by fluorescence microscopy. To investigate the specific uptake of PHEAEDA-P,C-Doxo into MDA-MB 231 cells with respect to HB-2 ones, co-culture experiments were conducted (Fig. 7). Cancer cells were stained with CellTrace CFSE fluorescent dye that gave them green fluorescence (b) and then they were mixed with the same amount of unlabelled normal cells. Therefore, nuclei of both cell lines were labelled with DAPI (a) and the samples were incubated with the conjugates (identified by the doxorubicin red auto-fluorescence, (c)).

The possibility of having in the same place both cancer and healthy cells could give us more information about the specific conjugate internalization. Indeed, after only 30 minutes of incubation, the red fluorescence was only in MDA-MB 231 cells and totally absent in the normal ones, revealing that there was a selective localization of PHEA-EDA-P,C-Doxo into cancer cells. Probably, this was because of the different membrane composition (i.e. fatty acid and proteins) $)^{26,27}$ and fluidity of the two cellular types.

Co-culture experiments were carried out over time (30 min, 1 h, $2 \mathrm{~h}, 6 \mathrm{~h}$ and $24 \mathrm{~h}$ ), using also low PHEA-EDA-P,C-Doxo concentration and free drug as control. As expected, the conjugate preferentially entered cancer cells instead of throughout the cell culture. In particular, data showed
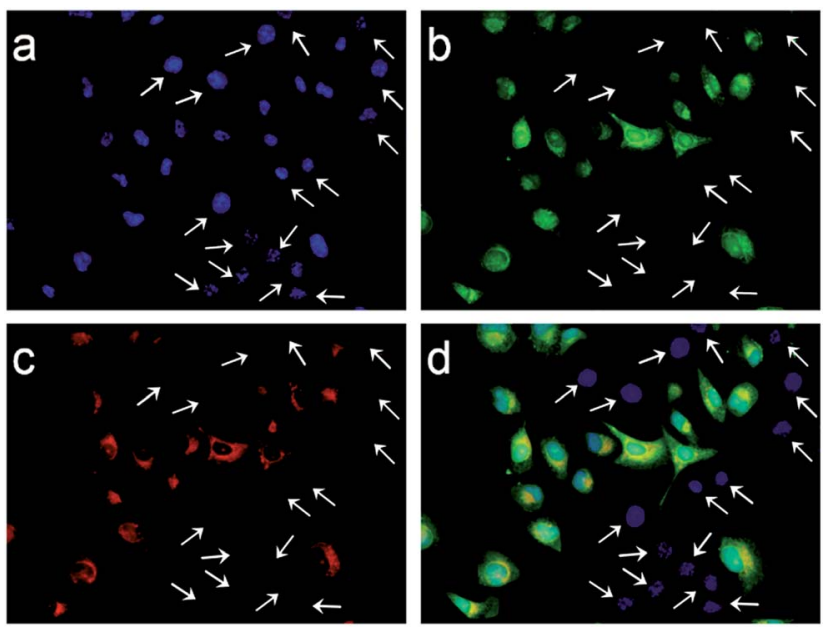

Fig. 7 Co-culture of MDA-MB 231 and HB-2 incubated for 30 min with $15 \mu \mathrm{M}$ PHEA-EDA-P,C-Doxo. The white arrows indicate the positions of HB-2 normal cells. Blue (a): nuclei; green (b): MDA-MB 231; red (c): Doxo; merge (d): overlay of 3 fluorescence signals. Magnification: $40 \times$

a selective localization of the conjugate in cancer cells even after short incubation times ( $30 \mathrm{~min} ; 1 \mathrm{~h} ; 2 \mathrm{~h}$ ). The red fluorescence, relative to Doxo, began to appear in HB-2 cytoplasm in $6 \mathrm{~h}$; subsequently ( $24 \mathrm{~h}$ of treatment) the drug was localized into the nuclei of both cell lines because it would enter in all cells by a diffusion process (see ESI, Fig. S4 †). By contrast, free doxorubicin was inside both cell lines already after 30 minutes of incubation, confirming the peculiar biological features of PHEA-EDA-P,C-Doxo (e.g., selectivity for cancer cells) (Fig. S5†).

PHEA-EDA-P,C-FITC-Doxo internalization mechanisms. Classical low molecular weight drugs enter cells especially through passive diffusion or active transport. By contrast, nanosystems enter cells via endocytosis by means of different mechanisms, depending on their physicochemical nature (hydrodynamic radius, lipophilicity and surface charge), involving membrane proteins or specific cellular pathways. ${ }^{28}$ The endocytosis pathway has been classified according to the proteins involved (like phagocytosis, clathrin-dependent or caveolae-dependent endocytosis and macropinocytosis). ${ }^{29}$ In order to investigate how PHEA-EDA-P,C-FITC-Doxo went inside normal and cancer cells, flow cytometric analysis and confocal microscopy assays were carried out using three inhibitors of specific endocytic pathways. In particular, ethylisopropyl amiloride (EIPA), ${ }^{30}$ phenylarsine oxide (PAO) ${ }^{31}$ and nystatin ${ }^{32}$ were used as inhibitors of micropinocytosis, clathrindependent and caveolae-dependent endocytosis respectively. The selected concentration of each inhibitor was first tested so as to ensure that they were not cytotoxic (i.e., cell viability near $100 \%$, data not shown). Cells treated with PHEA-EDA-P,CFITC-Doxo, without inhibitors, were used as negative control; while cells incubated at $4{ }^{\circ} \mathrm{C}$ were used as positive control, since low temperature blocks all the active internalization processes, so that the conjugates could only enter by a passive process (simple diffusion). Fig. 8 reports the flow cytometry data 


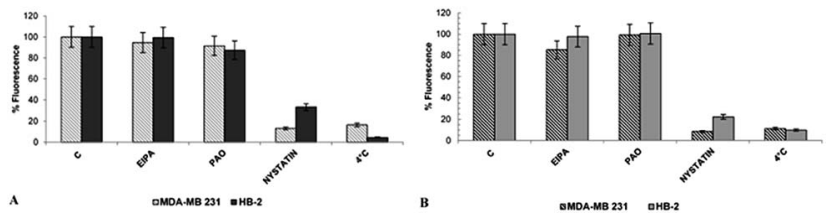

Fig. 8 Effect of various endocytic inhibitors on PHEA-EDA-P,CFITC-Doxo $(25 \mu \mathrm{M})$ internalization in MDA-MB 231 and HB-2 cells following both green (A) and red (B) fluorescence signals.

expressed as relative fluorescence (FITC, green; Doxo, red) calculated with respect to the negative control (assumed as 100\% signal) for MDA-MB 231 and HB-2 cell lines (Fig. 8A and B). In both cases, the samples treated with EIPA and PAO showed the same values as registered for the negative control; cells treated with nystatin presented low fluorescence levels similar to that of the positive control $\left(4^{\circ} \mathrm{C}\right)$, thus demonstrating that PHEA-EDA-P,C-FITC-Doxo enters cells prevailingly by caveolae-dependent endocytosis. Additionally, the red fluorescence (Doxo pendants) always followed the same trend observed for the green one (polymer backbone), implying that no significant drug release occurred during the uptake process. Indeed, it is known that free Doxo may diffuse across cell membranes by passive mechanisms and, as a consequence, it might be expected that the red fluorescence would have not been reduced after nystatin exposure. In agreement with the drug release experiments discussed above, these data point out that drug release is strongly activated inside lysosomes, at acidic $\mathrm{pH}$, after a partial hydrolysis of the conjugate at physiological $\mathrm{pH}$.

It is interesting to underline that nanosystem uptake in cancer cells was inhibited by nystatin more than in normal ones, probably due to the different membrane compositions. Therefore, these data confirm that, ostensibly, the membrane arrangement plays a key role in PHEA-EDA-P,C-FITC-Doxo internalization and determines the specific cancer cell uptake.
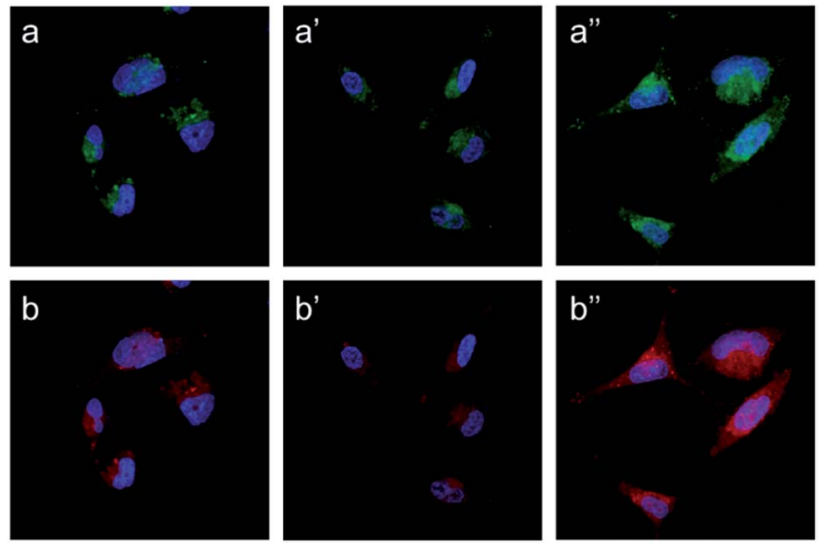

Fig. 9 Confocal microscopy images of MDA-MB 231 cells treated with nystatin and incubated with PHEA-EDA-P,C-FITC-Doxo (25 $\mu \mathrm{M})(\mathrm{a}$, b). Cells incubated at $4^{\circ} \mathrm{C}\left(\mathrm{a}^{\prime}, \mathrm{b}^{\prime}\right)$ were used as positive control and cells without inhibitor $\left(a^{\prime \prime}, b^{\prime \prime}\right)$ as negative control. Blue: nuclei. Green: PHEA $\left(a, a^{\prime \prime}\right)$. Red: doxorubicin (b, $\left.b^{\prime \prime}\right)$. Magnification $60 \times$
Confocal microscopy analyses of MDA-MB 231 cells treated with nystatin provided good insight into that, giving additional qualitative information (Fig. 9).

Both the green (conjugate) and the red (drug) fluorescence signals inside nystatin-treated cells (a and b) were very low, according to the positive control $\left(\mathrm{a}^{\prime}\right.$ and $\left.\mathrm{b}^{\prime}\right)$, in which they were on the cellular surfaces.

By contrast, in negative control, both dyes were diffused into the cytoplasm and the amount of conjugates was strongly evident.

Specific localization studies. Caveolae-mediated endocytosis, depending on the nature of the molecules, can involve two divergent mechanisms with different fates. For examples, SV40 virus can enter into the cells through a mechanism that can escape lysosomal degradation. ${ }^{33}$ On the other hand, some molecules using caveolae pathway are involved in the formation of early endosome, named caveosomes, that than fuse with lysosomes following the classical endocytic/digestion pathway. $^{34}$
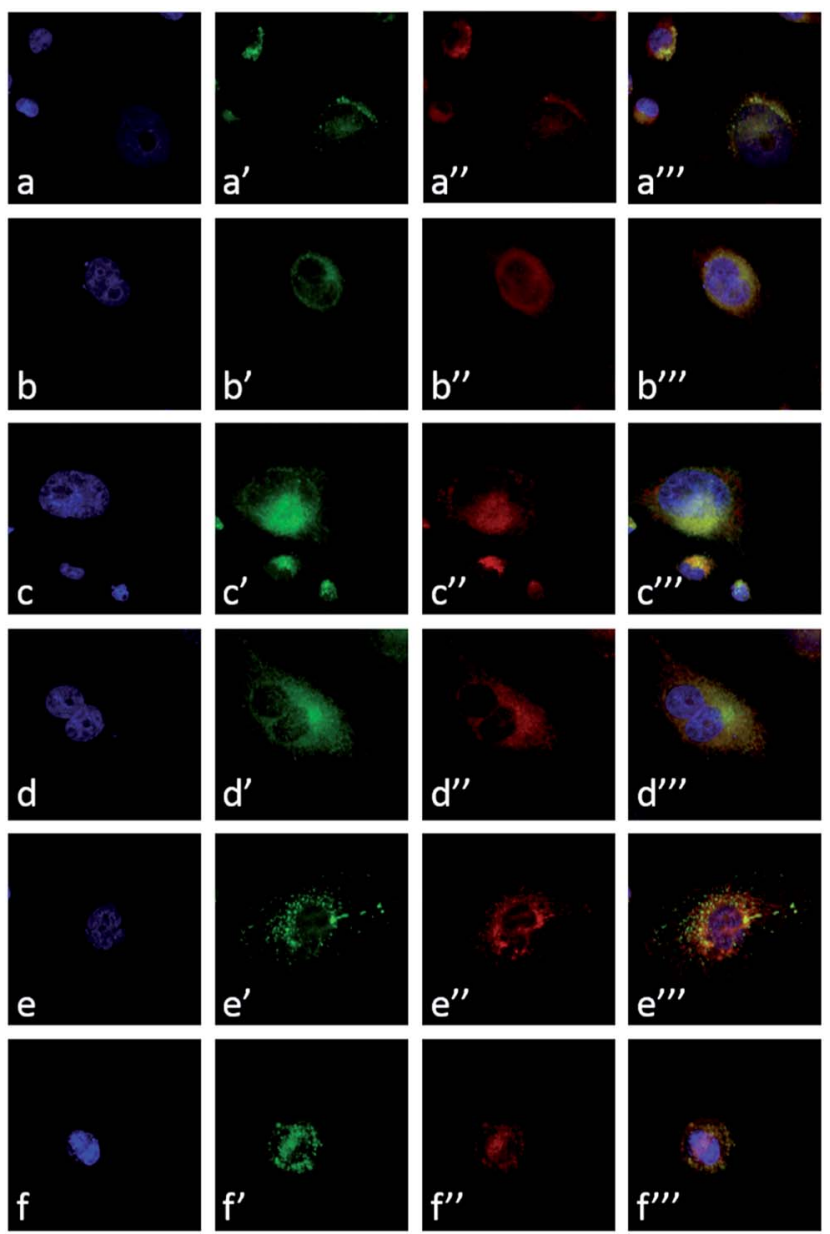

Fig. 10 Confocal microscopy images of MDA-MB 231 cells incubated with $10 \mu \mathrm{M}$ of PHEA-EDA-P,C-Doxo for $30 \mathrm{~min}\left(\mathrm{a}-\mathrm{a}^{\prime \prime \prime}\right), 1 \mathrm{~h}\left(\mathrm{~b}-\mathrm{b}^{\prime \prime \prime}\right), 2 \mathrm{~h}$ $\left(c-c^{\prime \prime \prime}\right), 4 h\left(d-d^{\prime \prime \prime}\right), 6 h\left(e-e^{\prime \prime \prime}\right)$ and $24 \mathrm{~h}\left(f-f^{\prime \prime \prime}\right)$. Blue: nuclei. Green: LysoTracker-labelled lysosomes. Red: doxorubicin. Merge: overlay of 3 fluorescence signals. Magnification 100x. 
We investigated the intracellular trafficking of PHEA-EDA$\mathrm{P}, \mathrm{C}-$ Doxo by confocal microscopy so as to establish which is its main preferred way for MDA-MB 231 cell internalization. In particular, MDA-MB 231 cells were incubated with the conjugates over time (30 min, $1 \mathrm{~h}, 2 \mathrm{~h}, 4 \mathrm{~h}, 6 \mathrm{~h}$ and $24 \mathrm{~h}$ ) and after that treated with LysoTracker, a specific marker that labels the lysosomal compartments inside the cells (Fig. 10a' $-\mathrm{f}^{\prime}$ ), in order to investigate a possible co-localization. After 30 minutes of incubation, the conjugate was still partially localized on cell surfaces, suggesting that it was going inside cells ( $\left.\mathrm{a}-\mathrm{a}^{\prime \prime \prime}\right)$. After 1 $\mathrm{h}$ of treatment, there was a preliminary and partial colocalization of the two fluorescence signals, even if the majority of the conjugate (red fluorescence) was still in the cytoplasm $\left(\mathrm{b}-\mathrm{b}^{\prime \prime \prime}\right)$. The fluorescence co-localization is evident after $2 \mathrm{~h}\left(\mathrm{c}-\mathrm{c}^{\prime \prime \prime}\right)$ and more after $4 \mathrm{~h}\left(\mathrm{~d}-\mathrm{d}^{\prime \prime \prime}\right)$ of treatment, showing that, once internalized by the claveolae mechanism, PHEAEDA-P,C-Doxo went into the lysosomal compartment to be hydrolyzed, thereby releasing the drug.

Indeed, after $6 \mathrm{~h}\left(\mathrm{e}-\mathrm{e}^{\prime \prime \prime}\right)$ the red fluorescence was no longer co-localized with the green fluorescence, but started to be evident in the nuclear area. Finally, after $24 \mathrm{~h}$ the cell nucleus appeared with classical apoptotic morphology due to the doxorubicin action $\left(\mathrm{f}-\mathrm{f}^{\prime \prime \prime}\right)$.

\section{Experimental section}

\section{Materials}

$\alpha, \beta$-Poly( $N$-2-hydroxyethyl)-D,L-aspartamide (PHEA), used as starting copolymer, was obtained as previously described. ${ }^{35,36}$ Doxorubicin hydrochloride (DOXO-HCl), $\mathrm{N}$-hydroxysuccinimide (NHS), 1-ethyl-3-(3-dimethylaminopropyl)carbodiimide hydrochloride (EDC-HCl), citraconic anhydride, and 4-pentynoic acid were purchased from Sigma-Aldrich and used as received. SpectraPor dialysis tubing was purchased from Spectrum Laboratories, Inc. (Italy).

Artificial lysosomal fluid (ALF) was obtained as previously reported. ${ }^{37}$

Human venous plasma and uncoagulated blood were obtained from healthy voluntary donors, in compliance with Italian laws (D.L. 191/2007; 2004/23/CE) and the University of Palermo guidelines, and immediately used. In particular, these samples were collected from the first co-author with his informed consent and the approval of the Bioethics Committee of the University of Palermo and the Italian Health Ministry.

${ }^{1} \mathrm{H}$ NMR spectra were recorded using a Bruker Avance II 300 spectrometer operating at $300.12 \mathrm{MHz}$. SEC was carried out using a Phenomenex PolySep-GFC-P3000 column (California, USA) connected to a Waters 2410 refractive index detector. A solution of $0.1 \mathrm{M} \mathrm{LiBr}$ in DMF was used as eluent at $50{ }^{\circ} \mathrm{C}$ with a flux of $0.6 \mathrm{~mL} \mathrm{~min}^{-1}$, and PEG standards (400-0.32 kDa, Polymer Laboratories Inc., USA) were used to set up a calibration curve $\left(R^{2}=0.9994\right)$.

Human breast cancer cells (MDA-MB 231) were maintained in Dulbecco's modified Eagle medium (DMEM) containing 10\% (v/v) fetal bovine serum (FBS, Euroclone, Celbar), 100 units per $\mathrm{mL}$ penicillin $\mathrm{G}, 100 \mu \mathrm{g} \mathrm{mL}{ }^{-1}$ streptomycin (Euroclone, Celbar) and $2 \mathrm{mM}$ L-glutamine (Euroclone, Celbar) at $37{ }^{\circ} \mathrm{C}$, in a humidified atmosphere of $5 \% \quad \mathrm{CO}_{2}$. Human mammary epithelial cells (HB-2) were grown in low-glucose DMEM (LGDMEM) supplemented with 10\% (v/v) FBS (Euroclone, Celbar), 100 units per $\mathrm{mL}$ penicillin $\mathrm{G}, 100 \mu \mathrm{g} \mathrm{mL}{ }^{-1}$ streptomycin (Euroclone, Celbar), $2 \mathrm{mM}$ L-glutamine (Euroclone, Celbar), $5 \mu \mathrm{g}$ $\mathrm{mL}^{-1}$ hydrocortisone (Sigma-Aldrich) and $10 \mu \mathrm{g} \mathrm{mL} \mathrm{m}^{-1}$ bovine insulin (Sigma-Aldrich) at $37{ }^{\circ} \mathrm{C}$ and $5 \% \mathrm{CO}_{2}$.

\section{Synthesis of PHEA-(2-aminoethyl)carbamate- pentine,citraconate (PHEA-EDA-P,C)}

PHEA-EDA was obtained as previously described..$^{38}$ PHEA-EDA (250 $\mathrm{mg}, 1.582 \mathrm{mmol}$ repeat unit) was solubilized in water (9 $\mathrm{mL}$ ), then NHS (14.5 mg, $0.1265 \mathrm{mmol}$ ) and EDC-HCl (24.26 mg, $0.1265 \mathrm{mmol}$ ) were added at once under stirring. At this stage 4pentynoic acid (12.4 $\mathrm{mg}, 0.1265 \mathrm{mmol}$ ) was added to the reaction mixture, the $\mathrm{pH}$ was adjusted to 6.5-6.8 with $0.1 \mathrm{M} \mathrm{NaOH}$, and the reaction was kept under occasional stirring for $15 \mathrm{~h}$ at $25{ }^{\circ} \mathrm{C}$. After that, the $\mathrm{pH}$ of the reaction was adjusted to 8.5 with $1 \mathrm{M} \mathrm{NaOH}$ and citraconic anhydride $(30.12 \mathrm{mg}, 0.268 \mathrm{mmol}$, in $1 \mathrm{~mL}$ anhydrous THF) was added dropwise to the crude reaction maintaining the $\mathrm{pH}$ within the range $8-9$ for $3 \mathrm{~h}$ using $1 \mathrm{M}$ $\mathrm{NaOH}$. The product was then purified from the by-products and unreacted monomers by means of exhaustive dialysis using a membrane tube with nominal molecular weight cutoff (MWCO) of 12-14 kDa. It was obtained as a brownish solid after freeze-drying. Yield: $170 \mathrm{mg}$. $\mathrm{Mn}=37$ 900, $\mathrm{PD}=1.81$.

${ }^{1} \mathrm{H}$ NMR $300 \mathrm{MHz}, \mathrm{D}_{2} \mathrm{O}: \delta 1.92$ (s, 1 $\left.\mathrm{H}_{\text {alchyne, }} \mathrm{CH}\right), 1.93$ $\left(\mathrm{m}, 3 \mathrm{H}_{\text {citraconate, }}{ }^{-} \mathrm{OOCCH}_{2} \mathrm{CH}_{3}\right.$ and $\left.\mathrm{NHCOCH}_{2} \mathrm{CH}_{3}\right), \quad 2.42$ (br, $4 \mathrm{H}_{\text {alchyne, }} \mathrm{CH}_{2} \mathrm{CH}_{2} \mathrm{C}$ ), 3.18 (br, $4 \mathrm{H}_{\mathrm{EDA}}, \mathrm{NCH}_{2} \mathrm{CH}_{2} \mathrm{~N}$ ), 3.39 (br, $2 \mathrm{H}_{\text {PHEA }}, \mathrm{CH}_{2} \mathrm{CH}_{2} \mathrm{NH}$ ), 3.60 (br, 2 $\mathrm{H}_{\text {PHEA }}, \mathrm{CH}_{2} \mathrm{CH}_{2} \mathrm{O}$ ), 4.06 (br, $\left.2 \mathrm{H}_{\mathrm{PHEA}}, \mathrm{CH}_{2} \mathrm{CH}_{2} \mathrm{OCONH}\right), 5.71$ (s, $1 \mathrm{H}_{\text {citraconate }} \mathrm{CHCOO}^{-}$), 6.35 (s, $1 \mathrm{H}_{\text {citraconate }}$ CHCONH).

\section{Synthesis of PHEA-(2-aminoethyl)carbamate- pentine,citraconate-doxorubicin (PHEA-EDA-P,C-Doxo)}

The conjugation of doxorubicin (Doxo) to PHEA-EDA-P,C was accomplished using a procedure previously reported. ${ }^{\mathbf{1 4}}$ Briefly, NHS (7.83 mg, $0.068 \mathrm{mmol})$, EDC-HCl (13.04 mg, $0.068 \mathrm{mmol}$ ) and doxorubicin hydrochloride $(39.4 \mathrm{mg}, 0.068 \mathrm{mmol})$ were added to a solution of PHEA-EDA-P,C (80 mg) in Milli-Q water/ DMF $6: 4(7 \mathrm{~mL})$. The $\mathrm{pH}$ of the reaction was maintained at 6.56.8 for $15 \mathrm{~h}$ at room temperature (min. $25{ }^{\circ} \mathrm{C}$, max. $30{ }^{\circ} \mathrm{C}$ ). Finally, the reaction was dialyzed through membrane tubing with MWCO of $1 \mathrm{kDa}$ and the pure product retrieved as a deep red powder. Yield: $85 \mathrm{mg} . \mathrm{Mn}=57800, \mathrm{PD}=1.61$.

${ }^{1} \mathrm{H}$ NMR $300 \mathrm{MHz}, \mathrm{D}_{2} \mathrm{O}: \delta 1.22\left(\mathrm{br}, 3 \mathrm{H}_{\text {doxo }}, \mathrm{CH}_{3} \mathrm{CH}_{2} \mathrm{O}\right.$ sugar ring), 1.91 (m, $3 \mathrm{H}_{\text {citraconate, }}{ }^{-} \mathrm{OOCCH}_{2} \mathrm{CH}_{3}$ and $\mathrm{NHCOCH}_{2} \mathrm{CH}_{3}$ ), 2.42 (br, 4 $\mathrm{H}_{\text {alchyne }}, \mathrm{CH}_{2} \mathrm{CH}_{2} \mathrm{C}$ ), 3.18 (br, $4 \mathrm{H}_{\mathrm{EDA}}, \mathrm{NCH}_{2} \mathrm{CH}_{2} \mathrm{~N}$ ), 3.39 (br, 2 $\mathrm{H}_{\mathrm{PHEA}}, \mathrm{CH}_{2} \mathrm{CH}_{2} \mathrm{NH}$ ), 3.60 (br, 2 $\mathrm{H}_{\text {PHEA }}, \mathrm{CH}_{2} \mathrm{CH}_{2} \mathrm{O}$ ), 4.06 (br, $\left.2 \mathrm{H}_{\mathrm{PHEA}}, \mathrm{CH}_{2} \mathrm{CH}_{2} \mathrm{OCONH}\right), 5.52\left(1 \mathrm{H}_{\text {doxo }}, \mathrm{O}-\mathrm{CH}-\mathrm{O}\right.$ anomeric sugar ring), $5.82\left(\mathrm{~s}, 1 \mathrm{H}_{\text {citraconate, }} \mathrm{CHCOO}^{-}\right), 6.44$ (s, $\left.1 \mathrm{H}_{\text {citraconate }}, \mathrm{CHCONH}\right), 7.00-8.00$ (br, $3 \mathrm{H}_{\text {doxo }}, \mathrm{CH}$ aromatic ring). 
Synthesis of FITC-labelled PHEA-EDA-P,C-Doxo (PHEA-EDAP,C-Doxo-FITC)

FITC-labelled PHEA-pentyne,citraconate-doxorubicin was obtained by dissolving PHEA-EDA-P,C-Doxo $(10 \mathrm{mg})$ in Milli-Q water $(5 \mathrm{~mL})$ and adding a solution of FITC $(1 \mathrm{mg}$ in $1 \mathrm{~mL}$ methanol) dropwise. The reaction was maintained at room temperature for 3 hours with stirring and purified by gel permeation chromatography using Milli-Q water as eluent (Sephadex-G15). After freeze-drying, an orange spongy solid containing $1 \mathrm{~mol} \%$ FITC was obtained. Yield: $8.1 \mathrm{mg}$. $\mathrm{Mn}=$ $58100, \mathrm{PD}=1.59$.

${ }^{1} \mathrm{H}$ NMR $300 \mathrm{MHz}, \mathrm{D}_{2} \mathrm{O}: \delta 1.22\left(\mathrm{br}, 3 \mathrm{H}_{\text {doxo }}, \mathrm{CH}_{3} \mathrm{CH}_{2} \mathrm{O}\right.$ sugar ring), 1.91 (m, $3 \mathrm{H}_{\text {citraconate, }}{ }^{-} \mathrm{OOCCH}_{2} \mathrm{CH}_{3}$ and $\mathrm{NHCOCH}_{2} \mathrm{CH}_{3}$ ), 2.42 (br, $4 \mathrm{H}_{\text {alchyne, }} \mathrm{CH}_{2} \mathrm{CH}_{2} \mathrm{C}$ ), 3.18 (br, $4 \mathrm{H}_{\mathrm{EDA}}, \mathrm{NCH}_{2} \mathrm{CH}_{2} \mathrm{~N}$ ), 3.39 (br, $2 \mathrm{H}_{\text {PHEA }}, \mathrm{CH}_{2} \mathrm{CH}_{2} \mathrm{NH}$ ), 3.60 (br, $2 \mathrm{H}_{\text {PHEA }}, \mathrm{CH}_{2} \mathrm{CH}_{2} \mathrm{O}$ ), 4.06 (br, $\left.2 \mathrm{H}_{\mathrm{PHEA}}, \mathrm{CH}_{2} \mathrm{CH}_{2} \mathrm{OCONH}\right), 5.52\left(1 \mathrm{H}_{\text {doxo }}, \mathrm{O}-\mathrm{CH}-\mathrm{O}\right.$ anomeric sugar ring), $5.82\left(\mathrm{~s}, 1 \mathrm{H}_{\text {citraconate }} \mathrm{CHCOO}^{-}\right), 6.44$ (s, $\left.1 \mathrm{H}_{\text {citraconate }}, \mathrm{CHCONH}\right), 7.00-8.00$ (br, $3 \mathrm{H}_{\mathrm{doxo}}, \mathrm{CH}$ aromatic ring).

\section{Chemical and physicochemical characterization of the nanosystems}

Determination of drug payload. The amount of doxorubicin linked in the PHEA-EDA-P,C-Doxo was determined spectrophotometrically. The absorbance of a solution of the conjugate in $0.1 \mathrm{M}$ phosphate buffer at $\mathrm{pH} 7.4\left(0.1 \mathrm{mg} \mathrm{mL}^{-1}\right)$ obtained at $480 \mathrm{~nm}$ was compared with those measured by serially diluting concentrations of doxorubicin hydrochloride. For comparative purposes, the content of drug loaded into the system was expressed as the amount of loaded doxorubicin hydrochloride per unit mass of polymer, and resulted to be $7.98 \%$ on a molar basis, corresponding to $21.81 \pm 0.3 \%(\mathrm{w} / \mathrm{w})$.

Aggregation study of the polymer conjugate at different concentrations. The chain arrangement changes of PHEA-EDA$\mathrm{P}, \mathrm{C}-$ Doxo as a function of the concentration was evaluated viscosimetrically in water, measuring the reduced viscosity $\left(\eta_{\text {red }}\right)$ of the conjugate in diluted regimen. In particular, it was measured for a concentration range of 0.01 and $0.125 \mathrm{~g} \mathrm{dL}^{-1}$ by using an Ubbelohde viscometer immersed in a cryostat bath at $25 \pm 0.1^{\circ} \mathrm{C}$. Each point was aaverage value of twenty consecutive measures with coefficient of variation $(\mathrm{CV} \%) \leq 3 \%$.

Doxorubicin cleavage studies. The release mechanism of doxorubicin from the conjugate was investigated by measuring $\zeta$-potential $(\mathrm{mV})$ variations at increasing $\mathrm{pH}$ values $(2-7)$. $\zeta$ Potential measurements were performed at $25{ }^{\circ} \mathrm{C}$ using a Malvern Zetasizer NanoZS instrument coupled with an MPT-2 accessory, fitted with a $532 \mathrm{~nm}$ laser at a fixed scattering angle of $173^{\circ}$. Aqueous solutions of either PHEA-EDA-P,C-Doxo or PHEA-EDA $\left(0.1 \mathrm{mg} \mathrm{mL}^{-1}\right)$ were analysed after filtration through a $5 \mu \mathrm{m}$ cellulose membrane filter. The $\mathrm{pH}$ titration of the copolymers was performed potentiometrically using $0.1 \mathrm{M}$ hydrochloric acid, previously filtered through a $0.22 \mu \mathrm{m}$ cellulose membrane filter, as acid standard. At each $\mathrm{pH}$ interval, the sample was recirculated inside cells for 2 minutes and then the $\zeta$-potential was measured. The $\zeta$-potential $(\mathrm{mV})$ was calculated from the electrophoretic mobility using the Smoluchowski relationship and assuming that $K a \gg 1$ (where $K$ and $a$ are the Debye-Hückel parameter and particle radius, respectively).

Drug release. Drug release studies were performed both in ALF ( $\mathrm{pH}$ 5.5) and in plasma. In a first set of experiments, PHEAEDA-P,C-Doxo (2.5 mg) was dissolved in ALF at pH $5.5(5 \mathrm{~mL})$ and placed into dialysis tubing with a MWCO of $2 \mathrm{kDa}$. It was then immersed into the medium $(35 \mathrm{~mL})$ and incubated at $37^{\circ} \mathrm{C}$ under continuous stirring (100 rpm) in a Benchtop 808C Incubator Orbital Shaker model 420, for $48 \mathrm{~h}$. Aliquots of the external medium ( $1 \mathrm{~mL}$ ) were withdrawn from the outside of the dialysis tubing at scheduled time intervals and replaced with equal amounts of fresh medium. The amount of doxorubicin released was evaluated by HPLC using C6-phenyl column and ACN/0.4 M ammonium phosphate buffer at pH $4 \pm 0.132: 68$ as mobile phase (flow $0.8 \mathrm{~mL} \mathrm{~min}^{-1}$ ). Then, the cumulative release was determined as a function of incubation time.

For the release experiment in plasma, $1 \mathrm{~mL}$ of a solution of the conjugate in plasma $\left(60 \mu \mathrm{g} \mathrm{mL}^{-1}\right)$ was placed into a test tube and incubated at $37{ }^{\circ} \mathrm{C}$. At scheduled time, one test tube was retrieved and methanol $(500 \mu \mathrm{L})$ was added to remove plasma proteins and the conjugate as well. After centrifugation $\left(4^{\circ} \mathrm{C}, 5\right.$ min, $5000 \mathrm{rpm})$ the supernatant was filtered through a syringe filter $(0.2 \mu \mathrm{m})$ and analyzed by HPLC using the method described above.

In a second set of experiments, PHEA-EDA-P,C-Doxo (2.5 $\mathrm{mg}$ ) was dispersed in human plasma $(2 \mathrm{~mL})$ and placed into a dialysis test tube with MWCO of $2 \mathrm{kDa}$, which was immersed in human plasma $(38 \mathrm{~mL})$. At fixed time intervals, $1 \mathrm{~mL}$ of plasma was collected and analyzed as described above. After $6 \mathrm{~h}$ of incubation at $37{ }^{\circ} \mathrm{C}$, the release medium was replaced with $\mathrm{ALF}$ at $\mathrm{pH} 5.5$ to simulate the release profile of the conjugate after cell uptake.

All release data were compared with the diffusion profile of doxorubicin hydrochloride alone $(0.5 \mathrm{mg})$ obtained by using the same procedure in order to rule out the retention of doxorubicin by the membrane dialysis. Data were corrected taking in account the dilution procedure. Each experiment was carried out in triplicate and the results were $\pm 5 \%$ standard error.

\section{Biological characterization of the nanosystems}

In vitro erythrocompatibility studies. Healthy erythrocytes were obtained by centrifuging $2 \mathrm{~mL}$ of fresh venous blood at $2200 \mathrm{rpm}$ for 10 minutes and by washing 5 times the pellet retrieved with $\mathrm{PBS}(\mathrm{pH}$ 7.4) until a colorless supernatant was observed. Then, to a solution of PHEA-EDA-P,C-Doxo in PBS $\left(\mathrm{pH} 7.4,2.5 \mathrm{mg} \mathrm{mL}^{-1}, 200 \mu \mathrm{L}\right)$ a $4 \% \mathrm{v} / \mathrm{v}$ suspension of erythrocytes $(200 \mu \mathrm{L})$ was added. The suspensions were incubated at 37 ${ }^{\circ} \mathrm{C}$ for $1 \mathrm{~h}$, centrifuged at $2200 \mathrm{rpm}$ for 10 minutes and the amount of hemoglobin released following erythrolysis was quantified spectrophotometrically at $570 \mathrm{~nm}$. All data were normalized using lysis buffer (Sigma-Aldrich) as positive control.

Cytotoxicity studies. MDA-MB 231 and HB-2 cells were seeded at a density of $1 \times 10^{4}$ cells per well in 96-well plates with the appropriate medium and allowed to adhere for $24 \mathrm{~h}$. Thereafter, cells were incubated for $24 \mathrm{~h}$ at $37{ }^{\circ} \mathrm{C}$ and $5 \% \mathrm{CO}_{2}$ 
with PHEA-EDA-P,C-Doxo or free doxorubicin as positive control at various drug concentrations from 0.5 to $25 \mu \mathrm{M}(0.5,2$, $3.5,5,10,15,20,25 \mu \mathrm{M})$. Untreated cells were considered as negative control. Cytotoxicity assay was conducted using Cell Counting Kit-8 (CCK-8) (Sigma-Aldrich): water-soluble tetrazolium salt (WST-8) is reduced by mitochondrial dehydrogenases of the living cells into soluble formazan dye that is directly proportional to the number of living cells. CCK-8 solution was added to each well in complete medium (dilution $1: 10$ ) and incubated for $2 \mathrm{~h}$ at $37^{\circ} \mathrm{C}$. The absorbance of each sample was read at a wavelength of $460 \mathrm{~nm}$ by a Synergy ${ }^{\mathrm{TM}}$ HT Multidetection microplate reader spectrophotometer (BioTek). The viability was expressed as percentage obtained from the ratio between each sample with respect to their negative control (100\% of cell viability).

Quantitative uptake studies. MDA-MB 231 and HB-2 cells were grown in 6-well plates. At confluence state they were incubated at $37{ }^{\circ} \mathrm{C}$ with PHEA-EDA-P,C-FITC-Doxo (final Doxo concentration of $25 \mu \mathrm{M}$ ) for $30 \mathrm{~min}, 2 \mathrm{~h}, 4 \mathrm{~h}, 6 \mathrm{~h}, 8 \mathrm{~h}$ and $24 \mathrm{~h}$. Successively, the samples were washed with PBS without $\mathrm{Ca}^{2+}$ and $\mathrm{Mg}^{2+}$, detached by trypsin-EDTA $1 \times$ in PBS (EuroClone) and collected by centrifugation at $1000 \mathrm{rpm}$ for $5 \mathrm{~min}$. The pellets were re-suspended in $500 \mu \mathrm{L}$ of PBS and analysed by a FACS-Canto cytometer (Becton Dickinson, Germany) detecting the green (FITC) and the red (Doxo) fluorescence emission (respectively 530 and $585 \mathrm{~nm}$ ). For each sample were collected $10 \times 10^{3}$ events investigated by BD FACS Diva software.

In vitro co-culture experiments. MDA-MB 231 cells $\left(10^{5}\right.$ cells per $\mathrm{mL}$ ) were stained with $25 \mu \mathrm{M}$ Molecular Probe CellTrace CFSE fluorescent stain (CellTrace CFSE Cell Proliferation Kit, Life Technologies) for 30 minutes at $37^{\circ} \mathrm{C}$.

Labelled MDA-MB 231 and unlabelled HB- 2 cells were mixed in a ratio of 1 : 1 and were grown at a density of $80 \times 10^{3}$ cells per well into 12 -well plates containing sterile coverslips in complete LG-DMEM for $24 \mathrm{~h}$ at $37^{\circ} \mathrm{C}$.

Thereafter, the cells were incubated with PHEA-EDA-P,CDoxo or free Doxo as positive control (final Doxo concentration of $10 \mu \mathrm{M}$ ) for $15 \mathrm{~min}, 30 \mathrm{~min}, 1 \mathrm{~h}, 2 \mathrm{~h}, 4 \mathrm{~h}, 6 \mathrm{~h}$ and $24 \mathrm{~h}$. Following, the cells were washed twice with PBS, fixed with $3.7 \%$ formaldehyde in PBS for 5 minutes and washed again with PBS. Furthermore, nuclei were labelled with DAPI for 15 minutes at room temperature. Untreated cells were used as negative control to set the auto-fluorescence. The samples were analysed by fluorescence microscopy (Leica).

Uptake mechanism study of PHEA-EDA-P,C-FITC-Doxo micelles. Internalization studies were conducted with MDA-MB 231 and HB-2 cell lines using flow cytometry and confocal microscopy. In both cases, the cells were pre-incubated for 10 minutes with PBS-G buffer (PBS with 5 mM 2-deossi-D-glucose) and then with different endocytosis inhibitors. The endocytosis inhibitors used were: $75 \mu \mathrm{M}$ EIPA; $40 \mu \mathrm{M}$ nystatin; and $5 \mu \mathrm{M}$ PAO. EIPA and nystatin were incubated for $10 \mathrm{~min}$ at $37^{\circ} \mathrm{C}$ while PAO for $5 \mathrm{~min}$ at $37^{\circ} \mathrm{C}$. Afterwards, PHEA-EDA-P,C-FITC-Doxo (final Doxo concentration of $25 \mu \mathrm{M}$ in PBS-G buffer) with EIPA or nystatin and without PAO were added and maintained for $1 \mathrm{~h}$ at $37^{\circ} \mathrm{C}$. Samples not treated with the inhibitors and incubated for the same time with PHEA-EDA-P,C-FITC-Doxo were considered as positive control, while cells incubated at $4{ }^{\circ} \mathrm{C}$ for $20 \mathrm{~min}$ and then treated with conjugates for $1 \mathrm{~h}$ were used to estimate the passive internalization.

For flow cytometry studies, cells were grown in 6-well plates with the appropriate medium until cell confluence. After treatment, they were washed with PBS without $\mathrm{Ca}^{2+}$ and $\mathrm{Mg}^{2+}$, detached by trypsin $1 \times$ (EuroClone) and centrifuged at 1000 rpm for 5 minutes in order to obtain a cell pellet that was resuspended into $0.5 \mathrm{~mL}$ of PBS. The samples were analysed by a FACS-Canto cytometer (Becton Dickinson, Germany) detecting the green (FITC) and the red (Doxo) fluorescence emission (respectively 530 and $585 \mathrm{~nm}$ ). For each sample were collected 1 $\times 10^{4}$ events investigated by BD FACS Diva software.

For confocal microscopy studies, cells were seeded in 12-well plates containing sterile coverslips at a density of $5 \times 10^{3}$ cells per well at $37{ }^{\circ} \mathrm{C}$ and after $24 \mathrm{~h}$ were treated with nystatin inhibitor as described above. After washing twice with PBS, cells were fixed with $3.7 \%$ formaldehyde for 5 minutes. Nuclei were labelled with DAPI for 15 minutes at room temperature and the samples were detected by a FLUOVIEW FV10i-LIV (Olympus). Cells treated with PHEA-EDA-P,C-FITC-Doxo were considered as positive control and cells inhibited by $4{ }^{\circ} \mathrm{C}$ treatment as negative control.

Intracellular trafficking studies. MDA-MB 231 cells were grown at a density of $5 \times 10^{3}$ cells per well in 12 -well plates containing sterile coverslips in complete DMEM for $24 \mathrm{~h}$ at 37 ${ }^{\circ} \mathrm{C}$ and then incubated with $10 \mu \mathrm{M}$ PHEA-EDA-P,C-Doxo for 30 min, $1 \mathrm{~h}, 2 \mathrm{~h}, 4 \mathrm{~h}, 6 \mathrm{~h}$ and $24 \mathrm{~h}$. At the end of each time, samples were treated with $60 \mathrm{nM}$ LysoTracker® Red DND-99 (Thermo Fisher scientific) for $1 \mathrm{~h}$ at $37{ }^{\circ} \mathrm{C}$ and later washed twice with complete PBS and fixed with $3.7 \%$ formaldehyde for 5 minutes. After different washes with PBS, nuclei were labelled with DAPI for 15 minutes at room temperature. The samples were detected by confocal microscopy (FLUOVIEW FV10i-LIV, Olympus).

\section{Conclusions}

Although important advances have been made in the field of targeted cancer therapy, achieving a better clinical response and tolerability, low selectivity and specific side effects such as skin reactions and peripheral neuropathy often occur. ${ }^{39}$ Therefore, it is evident that further efforts must be made to meet the desired clinical outcomes.

In this paper, the synthesis of a copolymer bearing high-dose doxorubicin covalently linked to give self-assembling properties and $\mathrm{pH}$-dependent drug release is reported. This conjugate represents a relevant example of a new prodrug capable of selfassembling into micelles (diameter $\sim 15 \mathrm{~nm}$ ) at low concentration and, thanks to the pH-sensitive citraconylamide liker adopted to bind the drug into the polymer backbone, capable of releasing doxorubicin preferentially at cancer microenvironment and so inside lysosomes (acidic pH). The release profile obtained in plasma and ALF showed an enormous doxorubicin release inside lysosomes after plasma exposure, thus demonstrating that this prodrug is prone to circumvent in vivo drug resistance phenomena. 
Cell viability assay carried out with normal and cancer breast cell lines showed a selective cytotoxic effect toward the latter, with a maximum efficacy and EC50 values comparable to those of the free drug. Flow cytometry analysis and confocal microscopy of co-cultures of both cell types explained well why this was observed, showing that the conjugate enters only cancer cells up to $6 \mathrm{~h}$ after incubation. The mechanism of internalization of the conjugate was investigated both in normal and cancer cells by means of specific inhibition tests, together with intracellular trafficking studies, enabling us to suppose that prodrug micelles are internalized through a caveolae-dependent pathway to be fused with late lysosomes inside cytoplasm. Here, doxorubicin is released to get inside nuclei and to selectively kill cancer cells.

\section{Acknowledgements}

We thank Dr Gianpiero Buscarino, Mediterranean Center for Human Advanced Biotechnologies (Med-Chab), for performing the AFM analysis reported in this paper.

\section{Notes and references}

1 S.-M. Lee and S. T. Nguyen, Macromolecules, 2013, 46, 91699180.

2 P. M. Enriquez-Navas, J. W. Wojtkowiak and R. A. Gatenby, Cancer Res., 2015, 75, 4675-4680.

3 H. Maeda, T. Sawa and T. Konno, J. Controlled Release, 2001, 74, 47-61.

4 A. Ganoth, K. C. Merimi and D. Peer, Expert Opin. Drug Delivery, 2015, 12, 223-238.

5 G. Adamo, G. Giorgia, C. Natascia, S. Simona, A. Maria, C. Dispenza and G. Ghersi, Chem. Eng. Trans., 2014, 457-462.

6 C. Dispenza, M. A. Sabatino, N. Grimaldi, D. Bulone, M. L. Bondi, M. P. Casaletto, S. Rigogliuso, G. Adamo and G. Ghersi, Biomacromolecules, 2012, 13, 1805-1817.

7 L. Sun, Q. Wu, F. Peng, L. Liu and C. Gong, Colloids Surf., B, 2015, 135, 56-72.

8 R. K. Jain and T. Stylianopoulos, Nat. Rev. Clin. Oncol., 2010, 7, 653-664.

9 S. Hama, S. Itakura, M. Nakai, K. Nakayama, S. Morimoto, S. Suzuki and K. Kogure, J. Controlled Release, 2015, 206, 67-74.

10 S. Mishra, P. Webster and M. E. Davis, Eur. J. Cell Biol., 2004, 83, 97-111.

11 S. C. Owen, D. P. Y. Chan and M. S. Shoichet, Nano Today, 2012, 7, 53-65.

12 M. Hans, K. Shimoni, D. Danino, S. J. Siegel and A. Lowman, Biomacromolecules, 2005, 6, 2708-2717.

13 Y. Wang, J. Du, Y. Wang, Q. Jin and J. Ji, Chem. Commun., 2015, 51, 2999-3002.

14 Y. Liu, H. Piao, Y. Gao, C. Xu, Y. Tian, L. Wang, J. Liu, B. Tang, M. Zou and G. Cheng, Int. J. Nanomed., 2015, 10, 2295-2311.

15 N. Mauro, S. Campora, C. Scialabba, G. Adamo, M. Licciardi, G. Ghersi and G. Giammona, RSC Adv., 2015, 5, 3242132430 .
16 N. Mauro, C. Scialabba, G. Cavallaro, M. Licciardi and G. Giammona, Biomacromolecules, 2015, 16, 2766-2775.

17 M. Licciardi, C. Scialabba, C. Fiorica, G. Cavallaro, G. Cassata and G. Giammona, Mol. Pharm., 2013, 10, 43974407.

18 C. Sardo, B. Nottelet, D. Triolo, G. Giammona, X. Garric, J.-P. Lavigne, G. Cavallaro and J. Coudane, Biomacromolecules, 2014, 15, 4351-4362.

19 M. A. Casadei, G. Pitarresi, R. Calabrese, P. Paolicelli and G. Giammona, Biomacromolecules, 2008, 9, 43-49.

20 H. Maeda, J. Wu, T. Sawa, Y. Matsumura and K. Hori, J. Controlled Release, 2000, 65, 271-284.

21 C. Scialabba, M. Licciardi, N. Mauro, F. Rocco, M. Ceruti and G. Giammona, Eur. J. Pharm. Biopharm., 2014, 88, 695-705.

22 Y. Yamamoto, Y. Nagasaki, Y. Kato, Y. Sugiyama and K. Kataoka, J. Controlled Release, 2001, 77, 27-38.

23 F. S. Palumbo, A. Bavuso Volpe, F. Bongiovi, G. Pitarresi and G. Giammona, Macromol. Biosci., 2015, 15, 1605-1615.

24 D. Reischl and A. Zimmer, Nanomedicine, 2009, 5, 8-20.

25 L. E. Gerweck and K. Seetharaman, Cancer Res., 1996, 56, 1194-1198.

26 X. Meng, N. H. Riordan, H. D. Riordan, N. Mikirova, J. Jackson, M. J. González, J. R. Miranda-Massari, E. Mora and W. Trinidad Castillo, P. R. Health Sci. J., 2004, 23, 103106.

27 Z. Szachowicz-Petelska, B. Dobrzynska, I. Sulkowski and S. Figaszewski, J. Environ. Biol., 2010, 31, 845-850.

28 L. Kou, J. Sun, Y. Zhai and Z. He, Asian J. Pharm. Sci., 2013, 8, 1-10.

29 G. J. Doherty and H. T. McMahon, Annu. Rev. Biochem., 2009, 78, 857-902.

30 S. Kälin, B. Amstutz, M. Gastaldelli, N. Wolfrum, K. Boucke, M. Havenga, F. DiGennaro, N. Liska, S. Hemmi and U. F. Greber, J. Virol., 2010, 84, 5336-5350.

31 A. I. Ivanov, Exocytosis and Endocytosis, ed. A. I. Ivanov, Springer, 1st edn, 2008.

32 R. D. Singh, V. Puri, J. T. Valiyaveettil, D. L. Marks, R. Bittman and R. E. Pagano, Mol. Biol. Cell, 2003, 14, 3254-3265.

33 L. A. Carver and J. E. Schnitzer, Nat. Rev. Cancer, 2003, 3, 571-581.

34 A. L. Kiss and E. Botos, J. Cell. Mol. Med., 2009, 13, 12281237.

35 G. Giammona, B. Carlisi and S. Palazzo, J. Polym. Sci., Part A: Polym. Chem., 1987, 25, 2813-2818.

36 N. Mauro, C. Fiorica, P. Varvarà, G. Di Prima and G. Giammona, Eur. Polym. J., 2016, 77, 124-138.

37 M. R. C. Marques, R. Loebenberg and A. May, Dissolution Technol., 2011, 15-27.

38 M. Licciardi, M. Campisi, G. Cavallaro, M. Cervello, A. Azzolina and G. Giammona, Biomaterials, 2006, 27, 2066-2075.

39 T. Iwamoto, Biol. Pharm. Bull., 2013, 36, 715-718. 